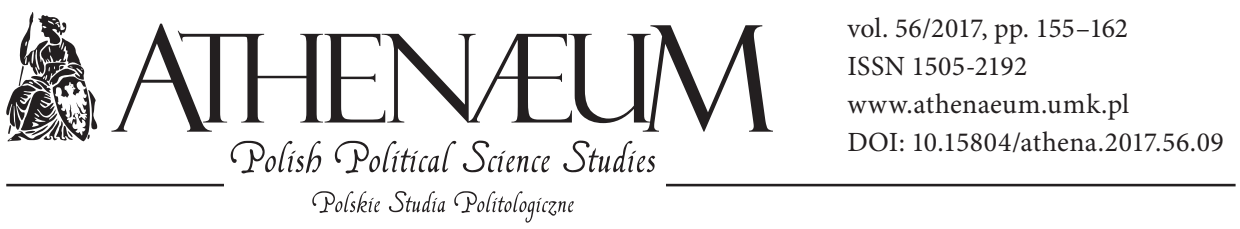

\title{
ATTRACTION ATTRIBUTION AS A THEORETICAL BASIS OF PUBLIC DIPLOMACY INSTRUMENTS EVALUATION
}

\author{
ATRYBUCJA ATRAKCYJNOŚCI JAKO TEORETYCZNA \\ PODSTAWA OCENY INSTRUMENTÓW DYPLOMACJI \\ PUBLICZNEJ
}

Marina Samsonova*

\begin{abstract}
- ABSTRACT
The article tackles the issue of measurement and evaluation of the effectiveness of public diplomacy instruments, such as strategies. The author suggests applying the approach based on the phenomenon of attraction. The evaluation of quality of public diplomacy is presented as the evaluation of influence of capabilities of public diplomacy instruments, and their certain set (aggregate) in subjective and functional strategies of public diplomacy. The article also argues a state that the more public diplomacy instruments meet the conditions of successful attraction and affiliation, the more likely they would be attractive to the population of a host country and would provide an involvement effect.
\end{abstract}

Keywords: public diplomacy, public diplomacy strategies, phenomenon of attraction, evaluation instruments
Artykuł dotyczy kwestii mierzenia i oceny skuteczności instrumentów dyplomacji publicznej, takich jak strategie. Autorka proponuje zastosowanie podejścia opartego na zjawisku atrakcyjności. Ocenę jakości dyplomacji publicznej przedstawiono jako ocenę wpływu skuteczności jej instrumentów oraz pewnego ich zestawienia w subiektywnych i funkcjonalnych strategiach dyplomacji publicznej. W artykule postawiono również tezę, że im bardziej instrumenty dyplomacji publicznej spełniają warunki skutecznego przyciągania i przynależności, tym bardziej będą one atrakcyjne dla ludności kraju przyjmującego oraz zapewnią efekt zaangażowania.

Słowa kluczowe: dyplomacja publiczna, strategie dyplomacji publicznej, zjawisko atrakcyjności, instrumenty oceny

\footnotetext{
* University of Warsaw, Faculty of Political Science and International Studies.
} 
The role of public diplomacy in the current international affairs is, undoubtedly, huge when compared to the era of classic interstate interaction. Public diplomacy as an instrument of research and building of public opinion, and also a tool of promotion of a state positive image abroad, is becoming one of the most influential means of international cooperation.

Public diplomacy as an instrument of a state's foreign policy is a relatively young phenomenon. Thus, its aims and values would not be of a great difference since mainly it is focused on development of its positive perception among foreign publics. Public diplomacy practices concern, for example, cultural and education cooperation with other states. Another important value of public diplomacy is international security and prevention of traditional international security threats. Thus, for instance, among current papers on public diplomacy issues there are some researches considering it in the context of traditional perception of this diplomacy, such as smart power combining both military and non-military means of international interaction. Mihai-Marcel Neag in his paper uses public diplomacy along with such concepts as military diplomacy and defense diplomacy, claiming the importance of all together in the sake of global collaboration and cooperation when dealing with the problems and opportunities brought about by economic interdependence, globalization, climate change, terrorism, and other matters (Neag, 2014). However, some new issues of public diplomacy would emerge with time and global development. Thus, for instance, with modern highly developed information and communication technologies, use of satellite and Internet technologies, public diplomacy turns into an instrument of global information influence, creating potential possibilities for completely new challenges.

In order to research public diplomacy of contemporary states, the criteria of effectiveness are quite necessary. Whilst operating these criteria, a researcher can evaluate efficacy of both - general public diplomacy strategy as well as the measures taken to implement it.

The researchers of the effectiveness of public diplomacy use various measure coordinates. Thus, according to Artem Tsvetkov, these criteria are the two indicators: approaching goals vs distancing from goals which are objectively achievable within the frames of public diplomacy; total vs fragmentary mobilization of resources which are available to the actors of public diplomacy (Tsvetkov, 2010).

The approach chosen here by the author of the paper is based on the phenomenon of attraction. This choice might be argued as follows. Science, culture, education, tourism, and sports obtain the potential of influence due to the fact 
that they provide mechanisms of attraction. According to a notorious American political scientist Joseph Nye, a state can achieve wanted results in world politics when other states are willing to follow the lead of this state, admiring its values, modeling themselves on the given example, and trying to reach its level of prosperity and openness. In such context it is crucial in world politics to shape agenda and attract others, rather than making them change by threatening to use military power or economic sanctions. Through such soft power others want the same things, and what is more, not by coercion, but by the means of attraction (Nye, 2004).

In practical implementation of international cooperation - from information technologies to bioengineering - a final strengthening of attractiveness of a nation state image indicates the presence of a public diplomacy direction (Tsvetkov, 2010).

Public diplomacy dimension is initially a measure of a potential of attractiveness of both certain public diplomacy strategies in whole, as well as single measures. The attractiveness of a state and its positive image are provided, in our opinion, by the quality of the instruments of public diplomacy strategies. The more attributes of the phenomenon of attractiveness of a subject/object there are, the higher the probability of its influence on a positive attitude towards a state. Therefore, in order to measure the quality of the instruments of public diplomacy, it is necessary to reveal an aggregate of features of the phenomenon of attractiveness of a subject/object - attraction.

In political and social psychology by the notion of attraction a positive orientation towards an "alien" in a form of interest, attention, sympathy, and friendly attitude is meant (Montoya, Horton, 2004). At the basis of the attitude there lie emotions and feelings, opinion of another person as an object of attention, positive attitude towards an "alien" might be explained by certain commonalities of people. The attraction paradigm of Donn Byrne stands for the claim that common points between two individuals increase their mutual sympathy, and, therefore, influence their interaction and behavior (Baron, Byrne, Johnson, 2003). In Russian scientific tradition of social psychology attraction is considered as both a process of moulding of object attractiveness, as well as a result, a product of this process, namely, positive attitude towards this object (Andreyeva, 2009).

Attraction as a social attitude of a friendly kind is essentially possible both among individuals (interpersonal), and among groups of people (intergroup). Social interpersonal attraction might be interpreted in several meanings: power 
and process of attraction; something pleasant, interesting; object which draws attention, meets expectations and taste; something people are willing to do, see, visit; a person encouraging sympathy; interaction which resists separation and aimed at concurrence (Merriam Webster's Collegiate Dictionary, 2016). Thus, as it can be inferred, in American tradition attraction is characterized in a wider manner, namely, as both a process of attraction, so as its intensity, the effect of which depends on an object, measures aimed at this object, and characteristics of a subject of attractiveness.

The potential of transformation of interpersonal contacts into fully functional interpersonal cooperation is contained in the following psychological determinants of attraction: need in affiliation, common kinship, regularity of interaction, and dimensional proximity (Shadricheva, 2016).

Dimensional proximity fairly creates availability of contacts with another person, facilitates obtaining information about them, in other words, it contributes to shaping their differentiated image and increases possibility of interaction with them. Dimensional proximity influences regularity of interaction. In the aggregate they increase the extent of acquaintanceship among individuals, decrease the influence of uncertainty factor, and, therefore, chance of threat, which influence increasing interpersonal attraction. However, mere dimensional proximity is not considered to be a determining factor, influencing attraction. Firstly, the effect of numerous interactions fades away in time. Secondly, life experience shows that people being in close proximity tend to not only choose, but also reject each other. Thus, it is necessary to take into consideration a number of factors.

The following factor determining interpersonal attraction is a need in affiliation, and namely, to create and maintain favourable relationships with other people, to have a will to be appealing, draw attention, interest, to have a feeling of being valuable and significant person.

The extent to which this need is expressed by different individuals indicates considerably their type of interpersonal behaviour. Those individuals whose need is mildly expressed tend to be seen as incommunicable, avoiding others. While those who express their need in affiliation to a greater extent are constantly looking for a contact with others, they are communicative, and trying to be noticed. For those with a strong need in affiliation general focus on people, their insolation intolerance happen to be factors increasing the attractiveness of a different individual, especially at the initial stage, as a potential communication partner (Buunk, 2001). 
Another factor of forming and developing attraction, pointed out by the researches, is a common activity. Experiments prove that common activities draw people together. However, they are rather common activities that result in success, even in the context of a game, that facilitate increase in attraction, than those that do not. Among the factors favourable for forming and development of attraction between subjects of common activity there are regularity of interactions between people as well as a fact of anticipation of joint meeting. George Homans in 1950 pointed out that if regularity of interaction increases, then the level of mutual sympathy grows, which also tends to work in reverse (Homans, 1984).

The factors considered above might be determined as external determinants of attraction because of the very fact that they appear for contextual or intrapersonal conditions, facilitating or restraining convergence of people. Apart from that, as soon as individuals make contact, a whole new group of factors appears, generated by the very process of interpersonal communication. Among the external, or in fact interpersonal, determinants of attraction there might be referred the following ones: physical attraction, communication style, regularity of interactions, convergence factor, complementation, supporting behaviour, successfulness, and emotional state.

According to some researches, there is a factor determining interpersonal attraction which states that people are eager to connect with those whose traits complete their own ones. A theory emphasizing differences instead of common people traits was suggested by an American psychologist Robert Winch, having named it a theory of complementary needs. The theory stands for the following: when choosing a spouse and even friends, people often chose those who fill their needs, and the highest extent takes place when two persons have complementary needs, rather than similar ones (Aronson, 1990).

The quality of public diplomacy strategies is determined by one more result, which is improvement of mutual understanding. Cultural diplomacy, according to Milton Cummings, is an exchange of ideas, information, values, traditions, beliefs, and other aspects of culture, which could facilitate improvement of mutual understanding (Cummings, 2003). Soft power is also an ability to attract, and often attraction leads to mutual understanding. In other words, when speaking in behavioural concerns, soft power is an attractive power, as J. Nye stated (Nye, 2003).

The mentioned above characteristics of attraction and conditions of its determination allow us to systemize criteria and attributes of quality of public 
diplomacy strategies and their instruments. Quality criteria in the aggregate characterize the extent of attraction intensity; attributes of criteria characterize the extent of low/high intensity of attraction:

1. instrument value - attributes: educative value (something pleasant, interesting; object which draws attention, meets expectations and taste of other people); personal value (object which draws attention, meets own expectations and taste);

2. distance between interests of actors and recipients - attributes: contemplative activity (something people are willing to do, see, visit); common activity (interaction which is opposed to separation and is aimed at concurrence);

3. frequency and periods of interpersonal interaction - attributes: single, maintaining.

These criteria and their attributes might be used as a standard of instrument quality of a public diplomacy strategy. It is important that rationalization, development, and realization of each instrument of strategies would be based on the mechanisms of attraction and its attributive characteristics. It is only in this case the effects of public diplomacy - propinquity effect and involvement effect - and, therefore, attractiveness of a state, its positive image, and values, could be expected.

The evaluation of quality of public diplomacy is the evaluation of influence of capabilities of public diplomacy instruments and their certain set (aggregate) in subjective (culture, science, education, economics, sport, and tourism) and functional (presence strategy, influence strategy) strategies of public diplomacy. It also concerns the involvement of a host state population in implementation of instruments and strategies of public diplomacy. The more public diplomacy instruments meet the conditions of successful attraction and affiliation, the more likely they would be attractive to the population of a host country, and would provide an involvement effect. This is the mechanism of how public diplomacy serves as an instrument of foreign policy of a state, providing influence on public opinion of the population of hosting states on the basis of stable state of mutual understanding, mutual relation, and cooperation of people of different cultures, nationalities, and countries, involved into practices of international cooperation in various public diplomacy strategies.

When speaking of practical instances of effectiveness evaluation, international educational exchange programs can be mentioned. They are considered to play a significant role in public diplomacy, basically, due to the assumption that direct 
first-hand contact between individuals of different nations diminishes stereotypical perceptions and prejudices as well as facilitates intercultural communication. Thus, Antonio F. de Lima Jr. points out their roles in his article as follows. Firstly, they are considered as a way to work in favor of improvement of an image of a country and to cast its foreign policy in a better light (de Lima, 2007). Secondly, de Lima states, that international educational exchange programs are "genuine fashion for governments to develop durable, stable relationships with foreign publics, which would also work for the successful implementation of foreign policy" (de Lima, 2007). Indeed, what would be expected from direct involvement of foreign students into a host society is their understanding of a host country including development of sympathy towards its culture and values, and further support for host's country foreign policy. Nevertheless, it is worth mentioning that the process of integration into a culture and also developing sympathy includes a variety of factors, which makes the process rather complicated and not necessarily ending in expected results. However, educational exchange programs are the key elements of public diplomacy of many countries, and they are considered as effective means of foreign policy. And since they are implemented through educational institutions, that makes universities and other establishments dealing with international education actors of public diplomacy of various countries, including Russia, and the United States.

Thus, for instance, speaking of the United States' experience in public diplomacy, de Lima quotes H. Finn, saying "if the US Department of State has a brand name around the world, that name is Fulbright" (de Lima, 2007). Indeed, Fulbright Program is a widely known international education exchange program of the US Department of State. According to the same paper, the Program played a crucial role in consolidating the leadership of the US in the post-WWII world, opposing communist ideology, spreading American ideas and values. Besides, after 9/11 through Fulbright program the US established exchange with the key countries, namely Afghanistan and Iraq, therefore increasing understanding of American society in the Islamic countries. Through educational exchange programs, including the Fulbright Program, it is possible to eliminate stereotypes and prejudices. International students play a role of culture carriers, therefore, providing mutual understanding at a direct personal level, which is unavailable in their home countries. Face-to-face contacts between representatives of different nations help diminishing stereotypical perceptions and facilitate crosscultural communication. The image of the United States in the world can show the effectiveness of its public diplomacy strategies. 
In our opinion, measurement and evaluation of a public diplomacy strategy on the basis of criterion of low/high intensity of attractiveness of public diplomacy instruments might contribute into optimization, and, thus, effectiveness of selecting by influence state a strategy according to current state of public opinion of a host state.

\section{ReFERENCES:}

Andreyeva, G.M. (2009). Social Psychology, $5^{\text {th }}$ ed. Moscow: Aspect Press.

Aronson, E. (1990). The Social Animal. Introduction to Social Psychology. Moscow: Progress.

Baron, R., Byrne, D., Johnson, B. (2003). Exploring Social Psychology. Saint-Petersburg: Piter.

Buunk, B.P. (2001). Affiliation, attraction, and close relationships. In: M. Houston, V. Strebe, J.M. Stephenson (eds.), Perspectives of Social Psychology (p. 372-379). Moscow.

Cummings Jr., M. (2003). Cultural Diplomacy and the United States Government. A Survey. Retrieved from: http://intranet.americansforthearts.org/by-program/ reports-and-data/legislation-policy/naappd/cultural-diplomacy-and-the-unitedstates-government-a-survey.

Homans, G. (1984). Social Behaviour as Exchange. Modern Foreign Social Psychology. Moscow: MSU Publishing.

de Lima Jr., A.F. (2007). The Role of International Educational Exchanges in Public Diplomacy. Place Branding and Public Diplomacy, 3(3), 234-251.

Merriam Webster's Collegiate Dictionary. Retrieved from: http://www.merriam-webster. com/dictionary/attraction.

Montoya, R.M., Horton, R. (2004). The Importance of Overall Evaluation as a Determinant of Interpersonal Attraction in the Similarity Effect. Journal of Personality and Social Psychology, 86(5), 696-712.

Neag, M. (2014). Promoting Security Through Public Diplomacy. Revista Academiei Fortelor Terestre, 19(2), 160-167.

Nye, J.S. (2004). Soft Power. The Means to Success in World Politics. Cambridge, MA: Public Affairs.

Shadricheva, A.I. (2016). Main Psychological Determinants of Interpersonal Attraction. East European Scientific Journal. Psychologia, 7(2), 180-183.

Tsvetkov, A.U. (2010). Public Diplomacy as a Source of Foreign Policy: Effectiveness Issue. Vestnik of $S P b U, 3,110-116$. 